\title{
Bio-electrode in Mechanistic Study of Lipoxygenase with Fatty Acids from Cooking Palm Oil
}

\author{
Zahraa A. Jarjes ${ }^{\mathrm{a}}$, Mohammed Razip Samian ${ }^{\mathrm{b}}$ and Sulaiman Ab Ghani ${ }^{\mathrm{a}, *}$ \\ ${ }^{a}$ Pusat Pengajian Sains Kimia, Universiti Sains Malaysia, 11800 USM Pulau Pinang, Malaysia \\ ${ }^{b}$ Pusat Pengajian Sains Kajihayat, Universiti Sains Malaysia, 11800 USM Pulau Pinang, Malaysia
}

\begin{abstract}
In this work a two-enzyme system catalyzing two consecutive reactions, namely, (i) Candida rugosa lipase type VII hydrolyzed the cooking palm oil producing fatty acids and (ii) soybean lipoxygenase-1 (type I-B) (SLO) in modified Nafion membrane carbon electrode oxidized the fatty acids to generate cathodic current. The hydrolysis was optimum at $\mathrm{pH} 7.5$, temperature $37{ }^{\circ} \mathrm{C}$, incubation time $60 \mathrm{~min}$ and the respective weights of enzyme and substrate 0.1 and $2 \mathrm{~g}$. Cyclic voltammograms at the optimized conditions showed that the introduction of lipase to the substrate of oil emulsion has increased the cathodic current density. Parameters such as potassium phosphate buffer (pH 7) and SLO (0.4 mg mL-1) were also crucial for a higher current density. The dodecyl trimethyl ammonium bromide, used to modify the Nafion membrane, was found to be the most suitable salt for the immobilization of the lipoxygenase enzyme. The results indicate that this could provide the basis for the construction of a bio-cathode in the bio-fuel cell.
\end{abstract}

Keywords: Cathodic current, Cooking palm oil, Hydrolysis, Lipase, Lipoygenase.

\section{INTRODUCTION}

During hydrolysis of natural oil and fat, its main ingredient triglyceride is stepwisely converted into diacylglycerol, monoacylglycerol and glycerol with fatty acid liberated at each step [1]. This hydrolysis, if it is catalyzed chemically, always require, high pressure and temperature which may then affect the properties of fatty acids in the triacylglycerol mixtures and may also end up producing undesirable compounds such as ketones and hydrocarbons [2]. The whole process is rather laborious when compared to the hydrolysis done using enzymes which can be carried out at room temperature and atmospheric pressure [3].

Lipases (EC 3.1.1.3) are a class of hydrolases that are primarily responsible for the hydrolysis of acyl glycerides [4]. Lipase is known to possess unique feature of acting at the aqueous and non - aqueous interfaces [5]. To date, the lipase from yeast Candida rugosa is the most often used enzyme than any other biocatalyst. This is due to its high activity in hydrolysis, synthesis, catalytic reactions, and broad specificities in various other applications [6].

Due to its specificity to a substrate, high catalytic activity, functioning at moderate temperatures and renewability, an enzyme is indeed very attractive to be utilized in the design of biofuel cells [7-9]. One of the enzymes of interest is lipoxygenase (E.C.1.13.11.12), a mononuclear non-heme iron dioxygenase enzyme found in both plants and animals [10]. It catalyses the incorporated oxygen into a $(1 Z, 4 Z)$-pentadiene system of polyunsaturated

*Address correspondence to this author at the Pusat Pengajian Sains Kimia, Universiti Sains Malaysia, 11800 USM Pulau Pinang, Malaysia;

Tel: +6 04653 4030; Fax: +6 04657 8454; E-mail: sag@usm.my fatty acids to form hydroperoxy-fatty acids [11]. The biofuel cell using lipoxygenase in catalyzing the oxidation of the fatty acid components of soybean oil has been reported [12]. The lipoxygenase-based biofuel cell has been found to be better than many of the alcohol and sugar-based biofuel cells.

This study reports on a bi-enzyme system catalyzing two consecutive reactions, consisting of the lipase-catalyzed hydrolysis of cooking palm oil (under the optimum conditions) and the subsequent lipoxygenation of liberated fatty acids using lipoxygenase immobilized in ammonium modified Nafion membrane on carbon electrode. Cyclic voltammetry was the main technique used to characterize the mechanism.

\section{MATERIALS AND METHODS}

\section{Chemicals}

Cooking palm oil was obtained from local stores. Candida rugosa lipase type VII and soybean lipoxygenase-1 (type I-B) (SLO) were purchased from Sigma-Aldrich (Japan). Other chemicals were of analytical grade and purchased from various sources. All solutions were freshly prepared using ultrapure water $(18.6 \mathrm{M} \Omega \mathrm{cm})$ from Milli-Q plus of Millipore Corp. (USA).

\section{Instrumentation}

Voltammetric experiments were carried out with electrochemical workstation Epsilon 2 of Bioanalytical System (BAS) (USA). A three electrode system was employed, with a platinum wire as counter electrode and pseudo $\mathrm{Ag} / \mathrm{AgCl}$ as the reference electrode. Voltammetric responses of $25 \mathrm{~mL}$ oil emulsion in potassium phosphate buffer ( $\mathrm{pH} 7$ ) were recorded at an applied potential of 500 to 
$1000 \mathrm{mV}$ (vs. $\mathrm{Ag} / \mathrm{AgCl}$ ). The $\mathrm{pH}$ of solution was obtained using $\mathrm{pH} / \mathrm{ISE}$ meter 720A from Orion (USA).

\section{Enzymatic Study}

\section{Assay of Lipase Activity}

The assay was adopted from Arima et al., [13] (One unit of lipase activity was defined as the amount of enzyme that librated 1 umole of free fatty acid per minute under test conditions). An oil emulsion was prepared as follows: $2 \mathrm{~g}$ polyvinyl alcohol (PVA) in $100 \mathrm{~mL}$ boiled water and then filtered. The PVA solution $(75 \mathrm{~mL})$ and oil $(25 \mathrm{~mL})$ were then blended in a homogenizer. An aliquot of the emulsion (5 mL) was added to $4 \mathrm{~mL}$ of phosphate buffer $(\mathrm{pH} 7.5)$ containing $0.1 \mathrm{~g}$ of lipase, and was then incubated in a water bath for $30 \mathrm{~min}$ at $37^{\circ} \mathrm{C}$. The hydrolysis was terminated by adding $20 \mathrm{~mL}$ of acetone-ethanol mixture $(1: 1 \mathrm{~V} / \mathrm{V})$. The free fatty acids in the mixture were then estimated by direct titration with $0.1 \mathrm{M} \mathrm{NaOH}$ in the presence of phenolphthalene as an indicator. The blank assay mixture was incubated without the added enzyme.

\section{Effect of $p H$, Temperature and Time}

The effects of $\mathrm{pH}$ and temperature on the activity of lipase were studied over the $\mathrm{pH}$ range 5.5 - 9.5 using phosphate buffers and incubation at temperatures between 20 to $50^{\circ} \mathrm{C}$ for $30 \mathrm{~min}$. The effect of time on lipase activity was determined at the optimum temperature and $\mathrm{pH}$ by varying the time of incubation between 1 to $5 \mathrm{~h}$.

\section{Effect of Substrate and Enzyme Weights on Lipase Activity}

Cooking palm oil was hydrolyzed using the same concentration of enzyme with incubation at $37{ }^{\circ} \mathrm{C}$ for $30 \mathrm{~min}$. Lipase activity for the substrate was measured as described above. The dependence of lipase activity on the substrate concentration was determined using $0.5,1,2,4,6$ and $8 \mathrm{~g}$ of cooking palm oil. To study the effect of enzyme concentration on the activity of lipase, up to $0.25 \mathrm{~g}$ of Candida rugosa lipases were used in the assay mixture containing cooking palm oil.

\section{Voltammetry Study \\ Preparation of Lipoxygenase Electrode}

A $1 \mathrm{~cm}^{2}$ of carbon sheet of Advent Research Material (UK) was first sonicated in methanol for several hours. Then, it was allowed to dry prior to modification. The lipoxygenase enzyme solution was prepared by adding $2 \mathrm{mg}$ of enzyme to $5 \mathrm{~mL}$ of phosphate buffer ( $\mathrm{pH} 7$ ). Casting solutions for making the mixture-cast membranes of Nafion and quaternary ammonium bromides were prepared as described elsewhere [14]. Enzyme and Nafion casting solutions, with a ratio of $1: 1$ were vortexed prior to coating on the electrode. The mixture was pipetted on the surface of $\mathbf{a}$
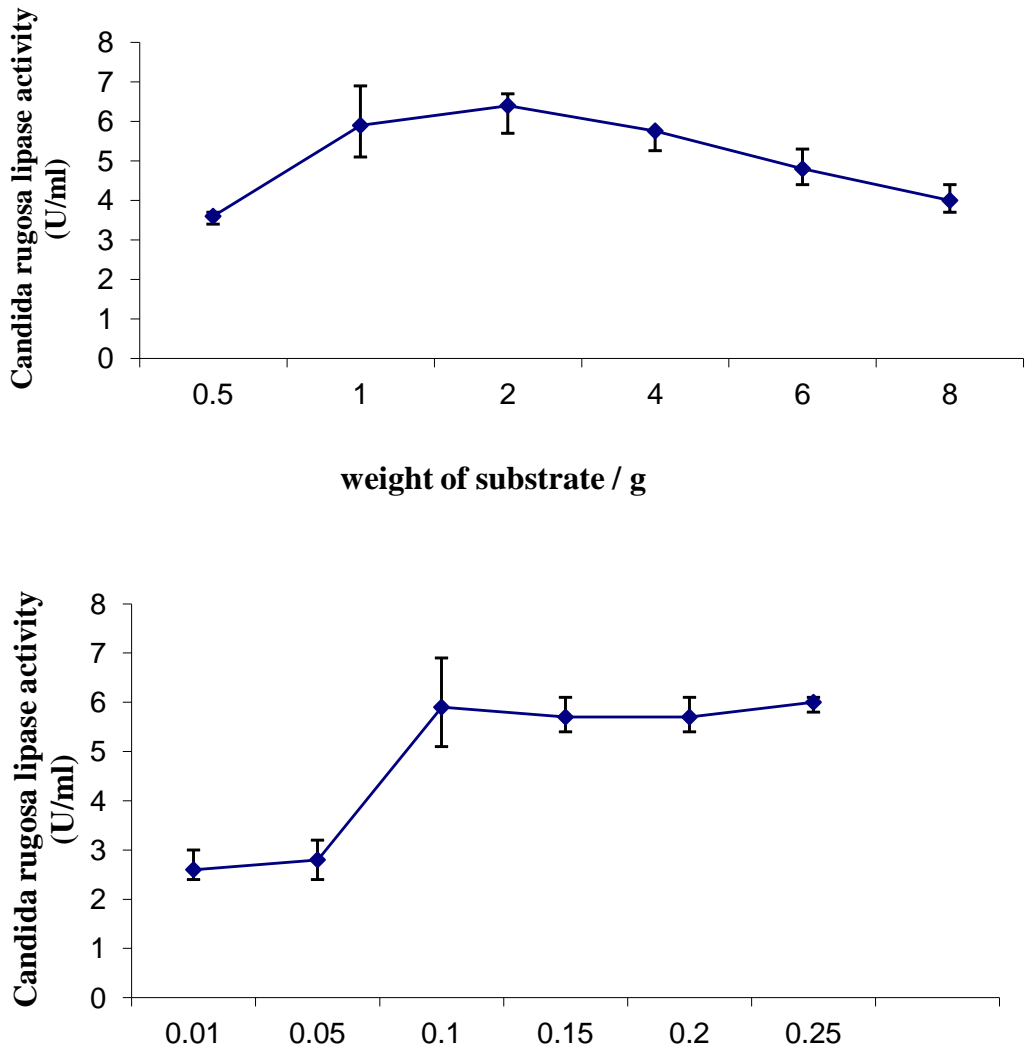

b weight of substrate / $\mathrm{g}$

Weight of enzyme / g

Fig. (1). (a) The effect of different concentration of substrate on the activity of lipase from Candida rugosa. (b) The effect of different concentration of enzyme on the activity of lipase from Candida rugosa. 
electrode and allowed to dry in a low humidity environment before any electrical measurement was made.

\section{Preparation of Emulsion}

An oil emulsion was prepared by mixing cooking palm oil $(2 \mathrm{~g})$ and $25 \mathrm{ml}$ phosphate buffer $\left(0.044 \mathrm{M} \mathrm{KH}_{2} \mathrm{PO}_{4}\right.$, $0.044 \mathrm{M} \mathrm{NaOH}$ and $0.15 \mathrm{M} \mathrm{NaCl})(\mathrm{pH} 7)$ containing $0.1 \mathrm{~g}$ lipase. The oil and aqueous phases were mixed and homogenized at room temperature for $30 \mathrm{~min}$ and then incubated at $37^{\circ} \mathrm{C}$ for $60 \mathrm{~min}$.

\section{RESULTS AND DISCUSSION}

\section{Lipase Activity}

\section{Effect of Oil and Enzyme Loading}

Fig. (1a) shows the effect of different substrate amounts on the activity of the Candida rugosa lipase. The enzyme activity was increased gradually as the oil amount increased from 0.5 to $2 \mathrm{~g}$ which may be due to the increase in substrate concentration and the interfacial area. At higher weights (exceeding more than $2 \mathrm{~g}$ ), there was a drop in the lipase which could be due to the active sites of lipase being saturated by the oil phase. This clearly indicates the limitation of lipase.

The plot of varying amounts of enzyme against a constant weight of substrate is shown in Fig. (1b). A steady increase in the activity of enzyme at weights up to $0.1 \mathrm{~g}$, with a very high rate of activity at enzyme weights between 0.05 and $0.1 \mathrm{~g}$, was observed which then starts to plateau between $0.1-0.25 \mathrm{~g}$. This may be due to the enzyme saturation of interface area between the oil and aqueous phase [15]. The result shows that the hydrolysis of $2 \mathrm{~g}$ of oil could be achieved at the enzyme weight of $0.1 \mathrm{~g}$.

\section{Effect of $\mathrm{pH}$ and Temperature}

The operating $\mathrm{pH}$ of the medium is critical to an enzyme's activity and selectivity. A report by Hernaiz et al., [16] on the stability of Candida rugosa lipase at various $\mathrm{pH}$ shows that the activity changes in relation to the conformation of the lipase protein. The "lid" may open or block the catalytic center for substrate binding [17]. This study demonstrates that the optimum $\mathrm{pH}$ for Candida rugosa lipase is pH 7.5 (Fig. (2a)). This shows that the enzyme performs well in a moderate alkaline medium but not in a very acidic or very alkaline medium.

A rise in temperature will increase the reaction rate of many hydrolysis. But at a higher reaction temperature, the enzyme tertiary structure may also be disrupted causing denaturation [18]. This phenomenon is illustrated in Fig. (2b). Although the enzyme activity declined at temperatures beyond $37^{\circ} \mathrm{C}$, substantial activity was observed even at $50{ }^{\circ} \mathrm{C}$, indicating the thermostability of the enzyme. Therefore, $37^{\circ} \mathrm{C}$ was selected as the optimum temperature.

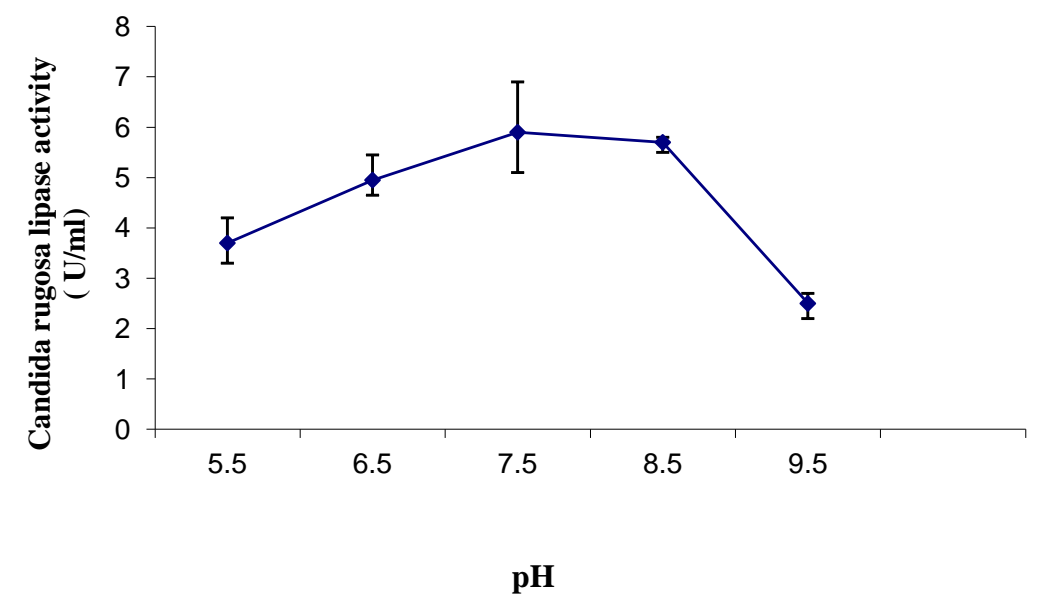

a

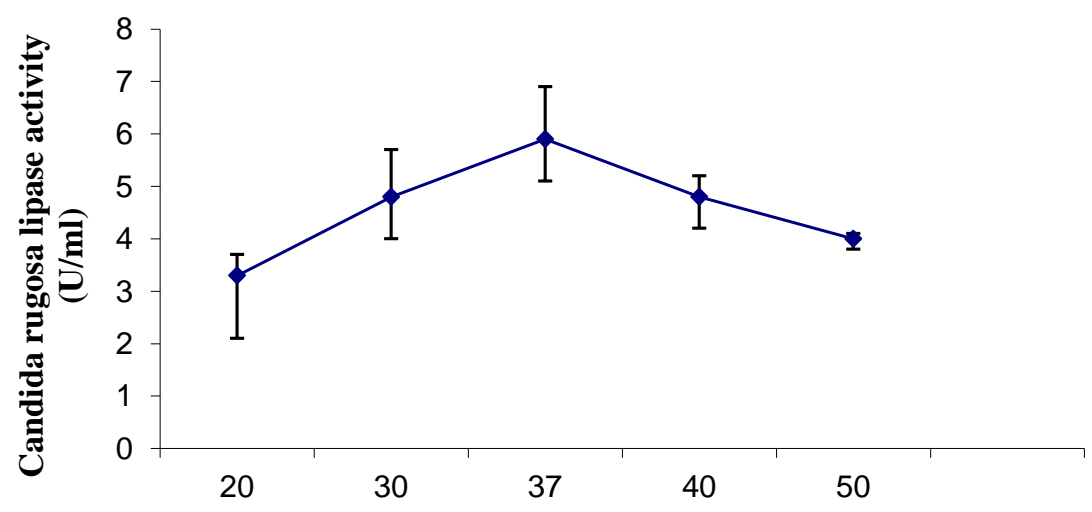

b

Temprature $/{ }^{\circ} \mathrm{C}$

Fig. (2). (a) The effect of $\mathrm{pH}$ on the activity of lipase from Candida rugosa. (b) The effect of temperature on the activity of lipase from Candida rugosa. 


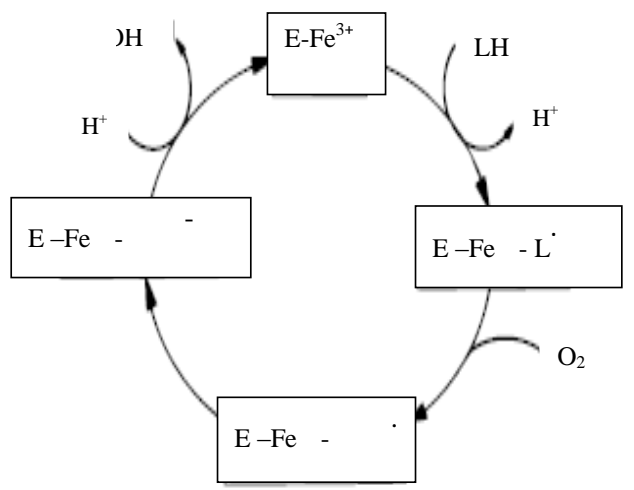

Fig. (3). Schematic mechanism of the oxygenation of lipids by lipoxygenase.

\section{Effect of Incubation Time}

The effect of incubation period on the activity of Candida rugosa lipase is studied (result not shown). The optimal activity was found to be $60 \mathrm{~min}$ of incubation. This agrees well with a report on this enzyme [19]. However, the activity decreases with time which might be due to the conversion of oil to the fatty acid at the interface of the oilaqueous solution, limiting the hydrolysis to occur on surface. Thus, the highest conversion occurs after the hydrolysis reaction has been completed in $60 \mathrm{~min}$ incubation.

\section{Mechanism of Lipoxygenation of Fatty Acids}

The two-enzyme catalysis in this work involves the coupling of (i) lipase-hydrolyzed cooking palm oil and (ii) lipoxygenation of the liberated fatty acid. The non-heme iron that is present in the lipoxygenase enzyme can be in two oxidation states: Fe (II) and Fe (III). This mediates the electron transfer reactions to form lipid peroxide [20]. Fig. (3) shows that once the enzyme is in the Fe (III) state, E$\mathrm{Fe}^{3+}$, it catalyzes a stereospecific abstraction of an $\mathrm{H}$ atom from a bis-allylic carbon atom onto the fatty acid side chain to form the potentially highly reactive alkyl radical (L') which remains bound to the protein. In this step the iron in the enzyme is reduced from the $\mathrm{Fe}$ (III) to the $\mathrm{Fe}$ (II). Oxygen then reacts with the alkyl radical to form the peroxyl radical (LOO') which is subsequently reduced by iron to form the peroxyl anion ( $\left.\mathrm{LOO}^{-}\right)$. Subsequently, this is released as a lipid hydroperoxide (LOOH) [21] after protonation. The hydroperoxy-fatty acids produced are detectable by the voltammetry technique.

\section{Cyclic Voltammetry Measurements}

\section{Study of Lipase Dependence}

Several isozymes of lipoxygenase exist, each often varying in the substrate specificity. Some of these isozymes have been reported [22] to act on acyl moieties in triglycerides as well as on free polyunsaturated fatty acids at room temperature. This means that cooking palm oil substrate emulsion contains some sites that are susceptible to attack by lipoxygenase in the absence of any added lipase. Fig. (4) shows that by introducing lipase to the substrate emulsion, the cathodic current density increases. The hydrolysis of ester bond of triacylglycerol facilitates the electron transfer reaction between lipoxygenase and the free fatty acids.

The lipoxygenase catalyzes the conversion of the product of the first enzymatic reaction, i.e. lipolysis. Fig. (5) indicates

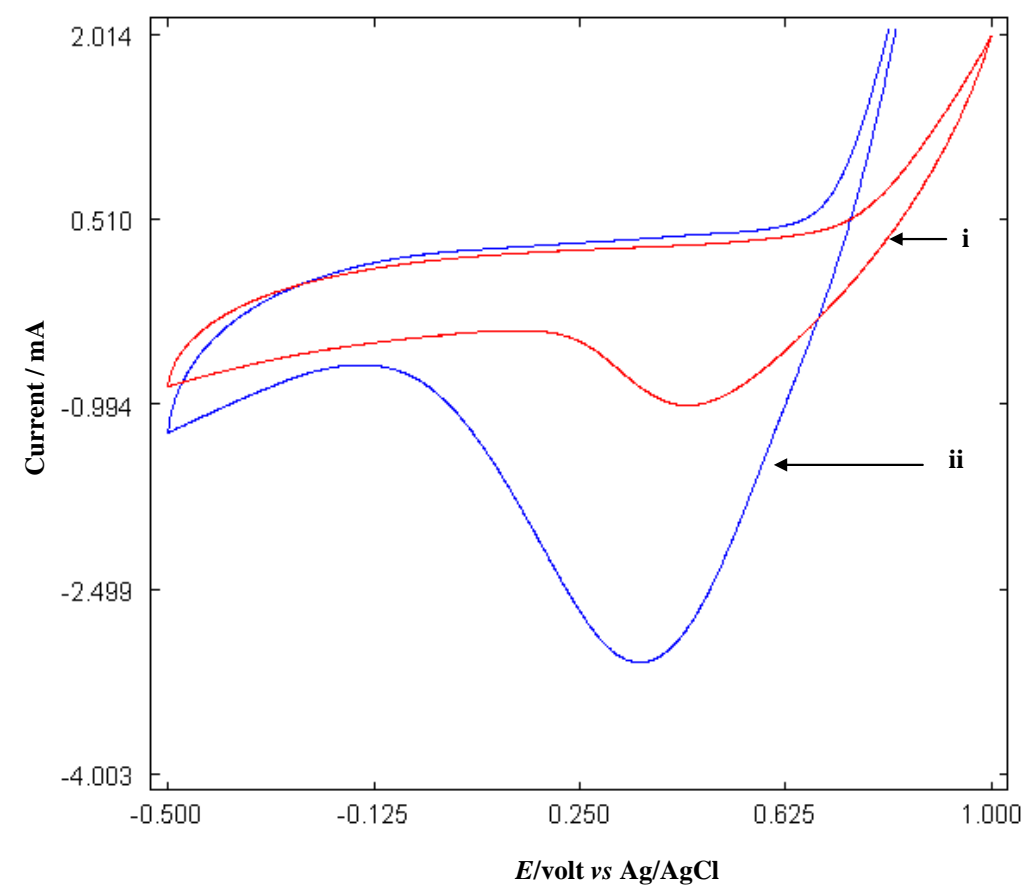

Fig. (4). The cyclic voltammograms of lipoxygenase-modified carbon electrode in the (i) absence and (ii) presence of lipase, scan rate $100 \mathrm{mVs}^{-1}$. 
that the highest current density is obtained at $0.1 \mathrm{~g}$ lipase which agrees well with the optimization of enzyme concentration of the lipase activity. It shows that the lipase produces free fatty acids that are utilized by lipoxygenase, which leads to an increase in performance of the latter. Therefore, the optimal amount of lipase used ensures a good balance between the levels of hydrolysis and oxidation of the lipids.

\section{Effect of Type of Buffer and $\mathrm{pH}$}

The enzyme activity depends on the types of salt used for buffering the system, which would then affect the current density produced. The effect of three different phosphate buffers i.e. (i) phosphate buffer saline (PBS) (0.044 M $\mathrm{NaH}_{2} \mathrm{PO}_{4}, 0.044 \mathrm{M} \mathrm{NaOH}$ and $0.15 \mathrm{M} \mathrm{NaCl}$ ) (ii) potassium phosphate buffer and (iii) sodium phosphate buffer $(0.2 \mathrm{M}$ $\mathrm{NaH}_{2} \mathrm{PO}_{4}, 0.2 \mathrm{M} \mathrm{Na}_{2} \mathrm{HPO}_{4}$ ) has been studied. Potassium phosphate buffer produces the highest current density (result not shown). However, sodium phosphate buffer produces the smallest current density. This is probably due to a small inhibitory effect of the sodium phosphate. Thus potassium phosphate buffer was chosen to further study the influence of different $\mathrm{pH}$.

As ionization of the substrate, as well as the lipoxygenase, would be affected by the $\mathrm{pH}$ of the reaction mixture, the influence of the $\mathrm{pH}$ buffer system on the peak current height is then examined. Fig. (6) depicts that $\mathrm{pH} 7$ gives the maximum current density over various $\mathrm{pH}$ between pH 5 - 9. The lipoxygenase showed a relatively broad $\mathrm{pH}$ activity profile. A substantial activity could be observed even at $\mathrm{pH}$ 9.0. This indicates that the low activity of the lipoxygenase at alkaline $\mathrm{pH}$ was not due to the inactivity of the enzyme, but rather due to the changes in the physical state of the substrate in the solution.

\section{Effect of Lipoxygenase Concentration}

The concentration of immobilized lipoxygenase on the substrate electrode was also studied. In order to determine the best operating condition, the concentration of lipoxygenase was varied. The investigation shows that $0.4 \mathrm{mg}$ $\mathrm{mL}^{-1}$ of SLO is required to get the optimum current density (Fig. 7). An enzyme content exceeding $0.4 \mathrm{mg} \mathrm{mL}^{-1}$ tends to decrease the current density. Thus, the amount of enzyme loaded on the substrate electrode is crucial.

\section{Optimization of the Nafion Membrane}

The cast films of quaternary ammonium salts and Nafion may have increased the mass transport of small analytes and decreased the selectivity of the membrane against anion [23]. Therefore, an investigation on the effect of various

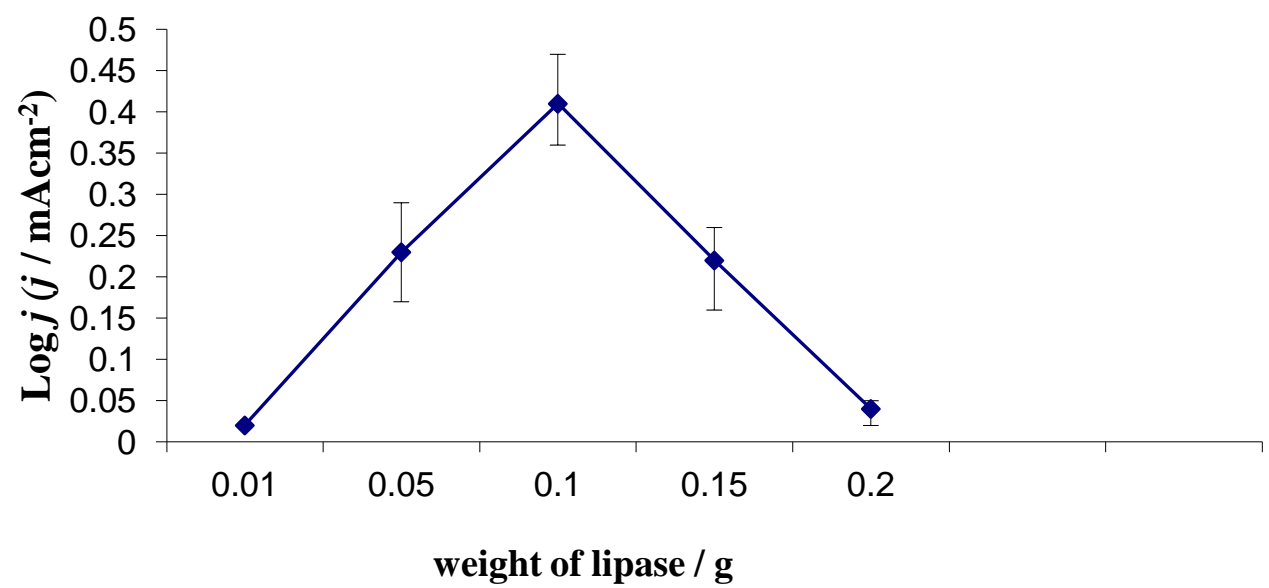

Fig. (5). The effect of different weight of lipase on the log current density.

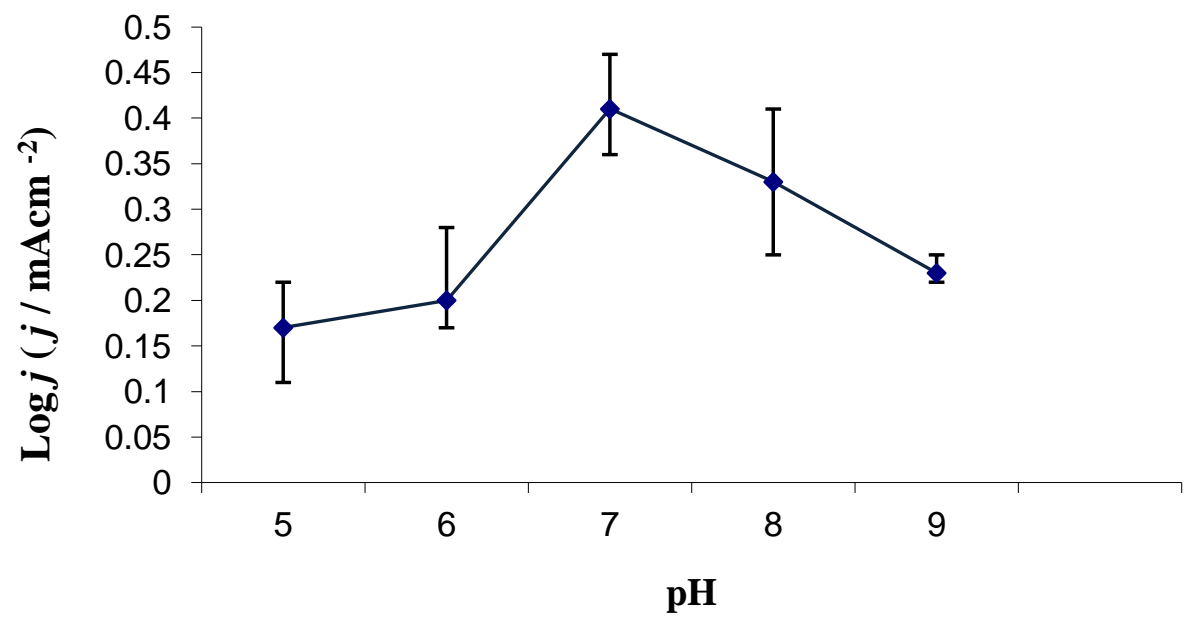

Fig. (6). Log current density of lipoxygenase modified carbon electrode at various $\mathrm{pH}$. 


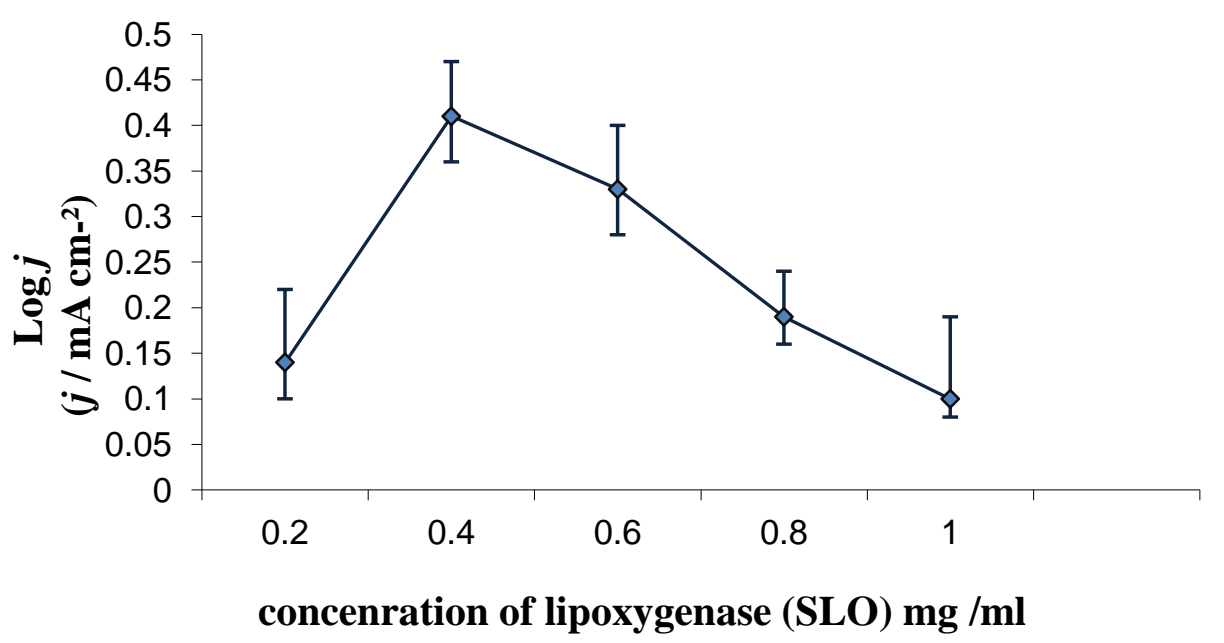

Fig. (7). Log current density of lipoxygenase-modified electrode at different concentration of lipoxgenase.

quaternary ammonium bromide salts used in the modification of Nafion membrane in the immobilization was done. It was found that the maximum current density was obtained when dodecyl trimethyl ammonium bromide was used in the modification of the Nafion membrane (Table 1). This is probably due to the existence of the large pore structure within the membrane left by the dissolved dodecyl trimethyl ammonium bromide, which then permits a large mass transport of the free fatty acids through the membrane to the active sites in enzyme.

\section{Table 1. The Current Density of Different Ammonium Salts}

\begin{tabular}{|l|l|}
\hline $\begin{array}{l}\text { Quaternary } \\
\text { Ammonium Bromide Salts }\end{array}$ & Log Current Density $\left.(\mathbf{m A ~ c m})^{-2}\right)^{\mathbf{a}}$ \\
\hline \hline Dodecyl trimethyl & $0.63 \pm 0.06$ \\
\hline Octyl trimethyl & $0.53 \pm 0.03$ \\
\hline Octadecyl trimethyl & $0.22 \pm 0.08$ \\
\hline Hexyl trimethyl & $0.41 \pm 0.01$ \\
\hline
\end{tabular}

${ }^{\mathrm{a}}$ Measurements were done in triplicate $(\mathrm{n}=3)$

\section{CONCLUSION}

In this work, the optimum conditions for the hydrolysis of cooking palm oil using Candida rugosa lipase have been studied. The released fatty acid was used as a substrate for lipoxygenase and the current generated was studied by cyclic voltammetry. The results show that the addition of lipase to the substrate emulsion has increased the current density due to the provision of free fatty acids for lipoxygenase. An increase in the current density is also obtained if the enzyme is immobilized on the dodecyl trimethyl ammonium bromide modified Nafion membrane. The present results are expected to be useful for the construction of a biofuel cell.

\section{CONFLICT OF INTEREST}

Declared none.

\section{ACKNOWLEDGEMENTS}

This study was sponsored by these Grants (i) 1001/PKIMIA/811044 and (ii) 1001/PKIMIA/842038. The University Fellowship Scheme to one of us (Z. A. Jarjes) is also appreciated.

\section{REFERENCES}

[1] Beisson, A.; Tiss, A.; Riviere, C.; Verger, R. Method for lipase detection and assay: critical review. Eur. J. Lipid Sci .Technol., 2000, 2, 133-153.

[2] Kittikun, A.H.; Prasertsan, P.; Sungpud, C. Continuous production of fatty acids from palm olein by immobilized lipase in a two-phase system. JAOCS, 2000, 77, 599-306.

[3] Al-Zuhair, S.; Hasan, M.; Ramachandran, K.B. Kinetic hydrolysis of palm oil using lipase. Process Biochem., 2003, 38, 1155-1163.

[4] Singh, M.; Singh, S.; Singh, R.S.; Chisti, Y., Banerjee; U.C. Transesterification of primary and secondary alcohols using pseudomonas aeruginosa lipase. Bioresour. Technol., 2008, 99, 2116-2120.

[5] Lee, S.; Hwang, S.; Lee, K.; Ahn, I. S. Microscopic analysis of ester hydrolysis reaction catalyzed by Candida rugosa lipase. Colloids Surf. B, 2006, 47, 78-84.

[6] Redondo, O.; Herrero, A.; Bello, J.F.; Roig, M.; Calvo, G.; Plou, F.J.; Burguillo, F.J. Comparative kinetic study of lipases A and B from candida rugosa in the hydrolysis of lipid p-nitrophenyl esters in mixed micelles with Triton X-100. Biochimica et Biophy. Acta, 1995, 1243, 15-24.

[7] Davis, F.; Higson, S.P.J. Biofuel cells-Recent advances and applications. Biosens. Bioelectron, 2007, 22, pp. 1224-1235.

[8] Li, G. Protein-Based Voltammetric Sensors: In: "Encyclopedia of Sensors", Craig, A.; Grimes Elizabeth, C.; Dickey, M.; Pishko, V. Eds., American Scientific Publishers, 2006, vol. 8, 301-313.

[9] Simon, E.; Halliwell, C.M.; Toh, C.S.; Cass, A.E.G.; Bartlett, P.N. Immobilisation of enzymes on poly(aniline)- poly (anion) composite films. Preparation of bioanodes for biofuel cell applications. Bioelectrochemistry, 2002, 55, 13-15.

[10] Goldsmith, C.R.; Jonas, R.T.; Stack, T.D.P. CH bond activation by a ferric methoxide complex: Modeling the rate-determining step in the mechanism of lipoxygenase. J. Am. Chem. Soc., 2002, 124, 83-96.

[11] Rejeb, I.B.; Hamida, J.B.; Gargouri, M. Coupled-enzyme system for the determination of lipase activity. Biotechnol. Lett., 2004, 26, 1273-1276.

[12] Kerr J.L.; Minteer S.D. Soybean oil biofuel cell: Utilizing lipoxygenase immobilized by modified Nafion ${ }^{\circledR}$ to catalyze the oxidation of fatty acids for biofuel cells. American Chemical Society publication. 2008, 986, 334-353. 
[13] Arima, K.H.; Wen, T.; Beppu, T . Lipase from bacillus. Agric. Biol. Chem., 1972, 11, 1913-1917.

[14] Moore, C.M.; Akers, N.L.; Hill, A.D.; Johnson, Z.C. Minteer, S.D. Improving the environment for immobilized dehydrogenase enzymes by modifying Nafion $^{\circledR}$ with tetra alkly ammonium bromides. Biomacromolecule, 2004, 5, 1241-1247.

[15] Rooney, D.; Weatherly, L.R. The effect of reaction conditions upon lipase catalyzed hydrolysis of high oleate sunflower oil in a stirred liquid-liquid reactor. Process Biochem., 2001, 36, 947-953.

[16] Hernaiz, M.J.; Rua, M.; Celda, B.; Medina, J.M. Contribution to the study of the alternation of lipase activity of Candida rugosa by ions and buffers. Appl. Biochem. Biotechnol., 1994, 44, 213-229.

[17] Benjamin, S.; Pandey, A. Isolation and characterization of three distinct forms of lipases from Candida rugosa produced in solid state fermentation. Braz. Arch. Biol. Tech., 2001, 44, 213-221.

[18] Romero, M.D.; Calvo, L.; Alba, C.; Daneshfar, A.; Ghaziaskar, H.S. Enzymatic Synthesis of isoamyl acetate with immobilized
Candida antartica lipase in hexane. Enzyme Microb. Tech., 2005, 37, 42-48.

[19] Khor, H.T.; Tan, N.H.; Chua, C.L. Lipase-catalyzed hydrolysis of palm oil. JAOCS, 1986, 63, 538-540.

[20] Muhammed, S.T.; Kariapper, I.; Dunham, W.R.; Funk, M.O. Iron extraction from soybean lipoxygenase-3 and reconstitution of catalytic activity from the apoenzyme. Biochem. Biophys. Res. Comm., 2001, 284, 563-567.

[21] Jones, G.D.; Russell, L.; Darley-Usmar, V.M.; Stone, D.; Wilson, M. T. Role of Lipid Hydroperoxides in the Activation of 15Lipoxygenase. Biochemistry, 1996, 35, 7197-7203.

[22] Pokorny, J.; Yanishlieva, N.; Gordon, M. Eds., Antioxidants in food practical applications. CRC; Woodhead Publishing Ltd. Cambridge, UK. 2001, pp 1-16.

[23] Schrenk, M.J.; Villigram, R.E.; Torrence, N.J.; Brancato, S.J.; Minteer, S.D. Effects of mixture casting Nafion (® with quaternary ammonium bromide salts on the ion - exchange capacity and mass transport in the membranes. J. Membr. Sci., 2002, 205, 3-10.

(C) Jarjes et al.; Licensee Bentham Open.

This is an open access article licensed under the terms of the Creative Commons Attribution Non-Commercial License (http://creativecommons.org/licenses/ by-nc/3.0/) which permits unrestricted, non-commercial use, distribution and reproduction in any medium, provided the work is properly cited. 